\title{
Diplomatická produkcia Filozofickej fakulty Univerzity Komenského v Bratislave v priereze jej existencie v rokoch 1921 až 1950
}

Ján Valo / jan.valo@uniba.sk

Katedra archívnictva a pomocných vied historických, Filozofická fakulta, Univerzita Komenského $\checkmark$ Bratislave

\begin{abstract}
This study attempts to illustrate the document production of the Faculty of Arts of Comenius University in Bratislava in the significant first phase of its rich history in the years 1920 to 1950. In this period, Comenius University in Bratislava underwent a fundamental change - its de jure demise and the subsequent establishment of the Slovak University in Bratislava. Paradoxically, however, this only had a slight effect on the internal organization and it did not fundamentally change documentation practices at the faculty. The article focuses not only on the written production of the faculty, but, in relation to the legislation in force at the time, it clarifies the faculty's activities and the functioning of its governing bodies and their mutual relations and powers. The work is based on information that was drawn mainly from preserved archival materials, which are now stored in the permanent archival custody and administration of the Archives of Comenius University in Bratislava. We also drew on archive documents from the National Archive in Prague.
\end{abstract}

\section{Keywords}

Comenius University in Bratislava; diplomatics; registry; document; university, first half of the 20th century

Príspevok je výstupom v rámci vedeckého projektu Agentúry na podporu vedy výskumu č. APVV-16-0383: Historický atlas miest Slovenska (Bratislava a Košice) - komplexný pamätový portál. 
Písomná či diplomatická produkcia je významným charakteristickým znakom nielen kancelárií vydavatelov najrozličnejších stupňov či druhov, ale aj pôvodcov neúradnej proveniencie - fyzických osôb. Jej štruktúra, zložitost', špecifické znaky, typológia písomností významnou mierou približujú daného vydavatel’a - úrad či organizáciu a ich vyspelost’ vo viacerých oblastiach. Ved' práve písomná produkcia, ktorá sa zachovala býva často jediným svedectvom existencie úradu či organizácie. Vysoké školy a univerzity boli odpradávna centrom vzdelanosti, kultúry či umenia. Sústred’ovali vzdelancov a do vel'kej miery poskytovali aj istú pluralitu názorov dokonca aj v časoch, ktoré týmto tendenciám všeobecne úplne nepriali.

Tento náš príspevok si vzal za svoj ciel priblížit písomnú produkciu na Filozofickej fakulte Univerzity Komenského v Bratislave a to v čase od jej vzniku v roku 1921 po rok 1950. Časové ohraničenie nie je náhodné, v roku 1950 bol totiž prijatý vysokoškolský zákon, ${ }^{1}$ ktorý mal univerzálnu celoštátnu platnost’ a na jeho základe sa pomerne podstatne zmenila aj dovtedajšia prax vo fungovaní nielen Filozofickej fakulty UK, ale aj všetkých jestvujúcich vysokých škôl v Československu. Tento zákon v podstate zakotvil nielen nové spôsoby fungovania vysokých škôl tak po stránke organizačnej a riadiacej, ale zaviedol aj inú tzv. pokrokovú kultúru úradovania a tým pádom aj písomnej produkcie vo vysokoškolskom prostredí.

Pri našom výskume sme sa priamo opierali už o doteraz publikované práce a to najmä týkajúce sa dejín Univerzity Komenského v Bratislave ako aj jej Filozofickej fakulty. Základ výskumu sa ale opieral o zachované archívne dokumenty pochádzajúce z činnosti fakulty. Dôvodom pre výber témy bola skutočnost', že predmetná problematika nebola doteraz spracovaná. Pri spracovaní témy sme rovnako zohladnili chronologický aspekt, rozhodli sme sa výskum zamerat’ na obdobie od vzniku fakulty po rok 1950, a to z dôvodu, že po druhej svetovej vojne resp. po roku 1950 nastáva na Filozofickej fakulte Univerzity Komenského v Bratislave (vtedy Slovenskej univerzity) množstvo zmien v oblasti produkovaných písomností a to tak po stránke kvantitatívnej ako aj kvalitatívnej. Samozrejme je nám jasné, že pre úplnost̉ a vyčerpanie problematiky bude potrebné v budúcnosti predlžit výskum až do súčasnosti resp. minimálne do konca 20. storočia. Pri práci sme aplikovali viacero metód - analytickú, komparatívnu (najmä vo vztahu k vlastnej registratúre fakulty), dôrazne sme sa opierali aj o poznatky z dejín správy univerzity a fakulty, ktoré sme zohl'adnili aj pri priblížení písomnej produkcie pôvodcu - teda Filozofickej fakulty.

Univerzita Komenského v Bratislave, v súčasnosti najväčšia a najstaršia fungujúca vysoká škola na Slovensku, začala písat svoju históriu iba pomerne nedávno - vznikla ako Československá štátna univerzita so sídlom v Bratislave v roku 1919. Zákon ktorým bola vysoká škola zriadená predpokladal tiež vznik štyroch základných fakúlt: lekárska, filozofická, právnická a prírodovedecká. Počas existencie prvej Československej republiky ale jestvovali iba prvé tri zmienené fakulty. ${ }^{2}$

1 Zákon č. 58/1950 Zb. z. o vysokých školách.

2 Zriadená na základe Zákona č. 375/1919 Zb. z. a n., ktorým sa zriaduje Československá štátna univerzita v Bratislave. Existencia týchto štyroch fakúlt vychádzala z prirodzenej potreby poskytovat komplexné univerzitné vzdelávanie pre obyvatelov Slovenska. Prírodovedecká fakulta Univerzity Komenského v Bratislave napokon vznikla až v nel’ahkých politických pomeroch v roku 1940 ako Prírodovedecká fakulta Slo- 
Filozofická fakulta Univerzity Komenského v Bratislave vznikla ako tretia v poradí na jeseň roku 1921. V spočiatku v nelahkých pomeroch a aj najmä v nie celkom vyhovujúcich priestorových podmienkach začala svoju činnost' 23. septembra 1921, kedy sa konalo prvé ustanovujúce zasadnutie Profesorského zboru fakulty, ktoré bolo najvyšším kolektívnym riadiacim orgánom fakulty. Podobné profesorské zbory, ako správne a riadiace kolektívne orgány, jestvovali aj na iných vysokých školách a to nielen v novej Československej republike, ale aj v okolitých krajinách. ${ }^{3} \mathrm{Na}$ tomto zasadnutí sa zúčastnilo celkovo sedem riadnych profesorov novovytvorenej fakulty, ktorí boli vymenovaní dekrétmi prezidenta Československej republiky. ${ }^{4}$ Boli to: Dr. Josef Hanuš, profesor dejín českej literatúry, Dr. Jan Heidler, profesor novších všeobecných dejín, Dr. Karel Chotek, profesor všeobecného národopisu, Dr. Dobroslav Orel, profesor hudobnej vedy, Dr. Albert Pražák, profesor dejín novšej českej a slovenskej literatúry, Dr. Jozef Škultéty, profesor slovenského jazyka a literatúry, a Dr. Miloš Weingart, profesor slovanskej filológie. Okrem nich to mali byt ešte d’alší dvaja profesori, ktorí ale na svoje funkcie nenastúpili - išlo o doktora Jána Radomila Kvačalu a Milana Hodžu. Na tomto prvom zasadnutí si profesori spomedzi seba zvolili prvého dekana Filozofickej fakulty UK a rovnako aj prvého prodekana. Dekanom sa vtedy stal profesor Josef Hanuš a prodekanom fakulty bol zvolený Jozef Škultéty. Okrem toho fakultu zastupoval v akademickom senáte univerzity vždy jeden senátor. ${ }^{5}$ Funkčné obdobie dekana ako aj prodekana trvalo jeden študijný (školský) rok. ${ }^{6}$

Písomná produkcia novo vzniknutej univerzity odzrkadlovala predovšetkým jej činnost' a pôsobnost'. Podobne ako aj v prípade iných inštitúcií či úradov sa registratúra členila do logických celkov. Spočiatku spôsob ukladania registratúry nebol taxatívne upravený a vychádzal zo vzoru iných vysokých škôl, najmä Karlovej univerzity v Prahe. Tento systém bol zavedený na Univerzite Karlovej v Prahe najmä v súvislosti s prvou svetovou vojnou a následnými udalostami po jej skončení. Vychádzalo sa z nutnej potreby rozdelit registratúry ako aj archív do aspoň základných vecných celkov, pretože prosté chronologicko-numerické členenie registratúry a z nej vzniknutého archívneho fondu pochopitel’ne

venskej univerzity v Bratislave. Vid' Zákon č. 168/1940 Sl. z. Do času kým nevznikla prírodovedecká fakulta niektoré vedné odbory realizovala Filozofická fakulta UK v Bratislave vo svojej vlastnej réžií. Spomenút možno napríklad výučbu zemepisu (geografie).

$3 \quad$ V tomto období neexistovali akademické senáty na fakultách Univerzity Komenského a preto práve tento orgán mal postavenie jediného kolektívneho riadiaceho orgánu. Akademický senát fundoval iba v rámci celej univerzity, kde jeho členmi bol rektor, prorektor, dekani a prodekani fakúlt univerzity, a d’alší delegáti (každú fakultu zastupoval jeden d’alší delegát v senáte). Pozri napr. Soznam osôb a ústavov univerzity Komenského v Bratislave, taktiež štátnych zkúšobných komisii vo štúdijnom roku 1922/23. Bratislava : Akademický senát Univerzity Komenského v Bratislave, 1992.

4 Fakulta vznikla na základe vymenovania prvých profesorov prezidentom Československej republiky dňa 14. septembra 1921 v Prahe, vid’ Novák, Jozef - Sopušková, Alžbeta: Filozofická fakulta Univerzity Komenského v Bratislave - Facultas Philosophica Universitatis Comenianae Bratislavensis. Bratislava 1987, s. 8.

5 Tamtéž. Pozri aj Univerzita Komenského v Bratislave - Archív Univerzity Komenského (d’alej AUK), fond Filozofická fakulta UK, škatula č. 5, sg. A - 1.

6 Dnes je vysokoškolským zákonom definované riadne úradné označenie akademický rok, avšak v období vzniku Univerzity Komenského v Bratislave sa v dokumentoch stretávame s dvojakým označením študijný rok ako aj školský rok, hoci termín študijný rok bol používaný v ovela hojnejšej miere. 
nepostačovalo potrebám na moderné ukladanie písomností. ${ }^{7}$ Registratúra fakulty bola pomerne pestrá už v prvých rokoch jej existencie. Dôležitú čast’ predstavovala agenda riadenia a správy fakulty - sem patrili aj písomnosti dekanského úradu (dekanátu), fakulta ako vzdelávacia organizácia mala pochopitel’ne širokú registratúru primárne vo vzdelávacej a študijnej agende. Okrem toho bola významná aj agenda vedy a výskumu. V neposlednom rade išlo o oblast financií a hospodárskej správy fakulty, veci týkajúce sa knižnice a napokon aj agenda l’udských zdrojov. Postupom času sa samozrejme tieto jednotlivé agendy viac diferencovali a narastali z hladiska kvantity. ${ }^{8} \mathrm{~V}$ nasledujúcich častiach príspevku priblížime nielen písomnú produkciu Filozofickej fakulty UK na viacerých jej úrovniach, a to na konkrétnych príkladoch, ale spomenieme aj organizačnú a riadiacu štruktúru fakulty. Rámcovo možno rozdelit diplomatickú produkciu fakulty na niekol'ko základných manipulačných období a to hlavne podla základnej koncepcie jej riadenia a vnútornej organizácie. Zaujímavé je, že prvé takéto obdobie pretrvalo od roku 1921 v podstate až do roku 1950.

Po vzniku fakulty v roku 1921 bol dekan fakulty jej najvyšším predstavitelom, riadil jej chod a reprezentoval ju navonok. Fakulta ním bola riadená na jeho priamu a osobnú zodpovednost'. Dekana zastupoval jeden prodekan v čase jeho neprítomnosti. V prípade, ak aj prodekan mal byt’ zastúpený, zastupoval ho služobne najstarší člen profesorského zboru. Dialo sa tak spravidla na základe častokrát aj ústneho poverenia. V prípade, ak by bol prodekan dlhodobo resp. trvalo zaneprázdnený a nemohol tak vykonávat svoju funkciu, na jeho miesto mal nastúpit prodekan z predchádzajúceho študijného roku. Okrem týchto dvoch hlavných predstavitel'ov riadil fakultu profesorský zbor, ktorého členmi boli riadne vymenovaní profesori. Tento najvyšší kolektívny riadiaci orgán riešil a rozhodoval o všetkých dôležitých otázkach chodu a smerovania Filozofickej fakulty. Zbor profesorov sa schádzal na zasadnutiach na ktorých sa veci vybavovali bud' písomným hlasovaním alebo uznesením schôdze. Takýmto spôsobom boli vybavované všetky veci a záležitosti, ktoré spadali do pôsobnosti profesorského zboru. Bežné a obyčajné záležitosti, kde sa aplikovali ustanovenia všeobecne záväzných právnych predpisov, nerozhodoval profesorský zbor, ale vybavoval ich priamo dekan s tým, že profesorskému zboru mal o tom podávat’ správy na jeho najbližšej schôdzi. Výnimka existovala v takých prípadoch, ak by následkom oneskorenia rozhodnutia jestvovalo pre fakultu isté právne riziko. $\mathrm{V}$ takom prípade mohol dekan fakulty rozhodovat sám s tým, že sa mal pokial' možno obrátit na príslušný odbor (úrad či inštitúcia), ktorého sa daná vec priamo dotýkala, a vyžiadat’ si stanovisko. V takomto prípade mal dekan dodatočne požiadat’ profesorský zbor o schválenie takéhoto rozhodnutia. Dekan okrem iného pripravoval prostredníctvom dekanstva (dekanátu) aj všetky vybavenia, ktoré boli potrebné pre vykonanie uznesení profesorské-

7 Pozri Polišenský, Ondřej: Inventár̆ Filozofické fakulty Univerzity Karlovy 1882-1966 (1970). Praha 1982, s. 12. Vzorom pre Univerzitu Komenského v Bratislave ako aj jej Filozofickú fakultu boli aj právne predpisy, ktorými sa riadila do velkej miery práve pražská Karlova univerzita. Táto bola vzorom aj pre iné vysoké školy v Československu. Buzek, Kamil - Placht, Otto - Havelka, František (Edd.): Přiručka školské a osvětové spráry. Praha 1934, s 34.

8 Významný posun nastal najmä po skončení druhej svetovej vojny a po otvorení nových pracovísk fakulty. 
ho zboru fakulty. ${ }^{9}$ Dekan fakulty mal zároveň kontrolnú funkciu voči činnosti dekanstva - zabezpečoval a dohliadal aby činnost’ kancelárie fakulty a jej pracovníkov bola správna a navyše zákonná. ${ }^{10}$ Tento spôsob riadenia a vedenia fakulty pretrval v podstate počas existencie celej prvej Československej republiky. Vychádzalo sa pritom z univerzitných tradícií, ktoré pretrvali dlhé desat'ročia najmä v Prahe či vo Viedni.

Ako sme už uviedli vyššie, profesorský zbor predstavoval najvyšší kolektívny riadiaci orgán fakulty, jeho členmi boli všetci riadni profesori Filozofickej fakulty Univerzity Komenského v Bratislave. Schádzal sa na pravidelných schôdzach, ktoré zvolával dekan fakulty alebo prodekan. Všetky záležitosti, ktoré bol kompetentný rozhodovat profesorský zbor, sa predkladali na jeho rokovania prostredníctvom správ. Každá takáto správa11 bola spracovaná jedným členom profesorského zboru - spravodajcom (referentom), ktorého určoval dekan fakulty. $\mathrm{V}$ dôležitých ako aj náročných veciach mohla mat̉ vec prikázaných dvoch prípadne aj troch spravodajcov. V takom prípade sa ustanovila komisia. Profesorský zbor mal zriadené aj stále výbory a stálych spravodajcov pre istú agendu. Išlo hlavne o veci študijné, knižničné a vedecké. Uvedené správy sa podávali vo forme exhibitov (výtahov) z podaní, ktoré boli adresované fakulte alebo jej vedeniu - dekanovi, prodekanovi či profesorskému zboru. V niektorých prípadoch sa na schôdzu predkladal ako prerokúvaný materiál aj celý spis, ktorý bol doplnený referátnikom obsahujúcim uvedenú správu od spravodajca veci. Tieto správy boli stručné ale výstižné, je predpoklad že boli prednášané spolu s ústnym komentárom, ktorý sa v niektorých prípadoch dostal do oficiálneho zápisu. Vec sa po prerokovaní v profesorskom zbore následne postúpila na konečné vybavenie spravidla na dekanát alebo ju vybavil príslušný gestor (spravodajca). ${ }^{12}$

Profesorský zbor mal pre isté agendy a záležitosti zriadené stále komisie. Komisii predsedal dekan, prodekan alebo v poradí d’alší služobne najstarší člen zboru. Každá takáto komisia mala svojho spravodajcu, ktorý predkladal zboru správy o prerokúvaných veciach. Ak mala komisia iba dvoch členov, boli obaja jej členovia spravodajcami. Každý člen profesorského zboru mal právo podávat samostatné návrhy vo všetkých veciach týkajúcich sa fakulty. Takéto samostatné návrhy bolo treba predkladat̉ aspoň tri dni pred danou schôdzou, v opačnom prípade sa takýto návrh prerokoval až na nasledujúcej schôdzi zboru. V prípade samostatného návrhu bol spravidla sám navrhovatel' aj spravodajcom návrhu. Samozrejme vyskytovali sa aj isté výnimky, najmä v prípade súrnych záležitostí, ktoré ale spravidla predkladal profesorskému zboru samotný dekan fakulty. Schôdze profesorského zboru boli riadne a mimoriadne. Riadne schôdze zvolával dekan

9 Dekan z hladiska svojho podpisového práva podpisoval vlastnoručne koncepty ako čistopisy vybavení. Tam, kde existovala domnienka dekana, že ani on a ani profesorský zbor nie je vo veci oprávnený konat a rozhodnút, mal dekan postúpit vec na konanie na Ministerstvo školstva a národnej osvety, ktoré malo v predmetnej veci rozhodnút s konečnou platnostou.

10 Národní archiv (dalej NA), fond Ministerstvo školství I., karton č. 1142, sg. 5 III 2, spis č. 129 505/1922, Rokovací poriadok profesorského zboru Filozofickej fakulty Univerzity Komenského v Bratislave - schválenie. Pozri aj AUK, fond Filozofická fakulta UK, škatula č. 5, sg. A - 1.

11 Správa mala obsahovat všetky dôležité informácie, podklady, najmä skutkový stav veci, v prípade potreby mal byt doložený aj predpis podla ktorého sa malo konat a rozhodnút. Návrh uznesenia vo veci mal mat spravidla formu konceptu vybavenia - najmä ak išlo o odpoved' alebo rozhodnutie. 
fakulty podla potreby, prípadne na dátum, na akom sa uzniesol zbor na svojom predchádzajúcom zasadnutí. Mimoriadne schôdze sa zišli v prípade ak o to písomne požiadala aspoň tretina členov profesorského zboru. Pozvánky boli zasielané v písomnej forme každému členovi zboru, ak tento nebol aktuálne na dovolenke, a to väčšinou minimálne deň pred konaním schôdze. V nutných prípadoch mohol dekan pozvat členov zboru aj v samotný deň schôdze. Na schôdzach profesorského zboru sa hlasovalo verejne alebo tajne, teda písomne - verejné hlasovanie sa uskutočnilo bud' zdvihnutím ruky alebo ústnym spôsobom. ${ }^{13} \mathrm{Z}$ každej schôdze profesorského zboru sa vyhotovila písomná zápisnica, ktorá obsahovala všetky dôležité informácie o jej priebehu, prítomných ako aj o uzneseniach zboru. ${ }^{14}$ Forma zápisníc sa počas existencie fakulty v prvej Československej republike zásadne nezmenila. Vyhotovené boli na papieri spravidla strojopisom, v niektorých prípadoch nájdeme aj rukou písané koncepty týchto zápisníc, ktoré ale v mnohých prípadoch obsahujú aj rozličné doplnkové informácie - väčšinou rozličné poznámky. ${ }^{15}$ Zápisnice boli priebežne číslované v rámci jednotlivých študijných rokov, neobsahovali teda ani spisové čísla a ani neboli evidované v podacích protokoloch fakulty. ${ }^{16}$ Číslovanie týchto zápisníc sa ale uskutočnilo až dodatočne, predpokladáme že pred ich odovzdaním z dekanstva do archívu univerzity. Počas prvej Československej republiky bola jazykom zápisníc čeština. Tento jav je celkom pochopitelný, pretože na celej univerzite bol vysoký podiel českých profesorov, ktorí sem prišli najmä z Karlovej univerzity v Prahe, prípadne aj z Masarykovej univerzity v Brne a pomáhali pri jej zrode a v tažkých časoch prvých rokov jej existencie. ${ }^{17}$ Vyskytli sa ale aj prípady, kedy zápisnica zo zasadnutia profesorského zboru má zachovanie iba vo forme rukopisu. Tu sa môžeme domnievat, že čistopis písaný na stroji sa v registratúrnom štádiu stratil a do archívu sa dostala už iba

13 Žiadny člen zboru sa nemohol hlasovania vzdat’ a musel jednoznačne hlasovat’ za alebo proti návrhu. Profesorský zbor používal pri hlasovaniach vo veciach ohladne menovania docentov a profesorov systém hlasovania pomocou guličiek, tzv. balotáž.

14 NA, fond Ministerstvo školství I., karton č. 1142, sg. 5 III 2, spis č. 129 505/1922, Rokovací poriadok profesorského zboru Filozofickej fakulty Univerzity Komenského v Bratislave - schválenie. Konkrétne išlo o údaje o dátume, čase a mieste konania schôdze. Zoznam prítomných, neprítomných a z toho ospravedlnených ako aj neospravedlnených členov zboru, ako aj meno zapisovatela. Oznámenia dekana fakulty ako aj odpovede na interpelácie. Ďalej bolo súčastou zápisnice zoznam vecí a záležitostí, ktoré boli prerokované na schôdzi v takom poradí, ako boli schválené v programe schôdze. Každá záležitost̉ bola označená rokovacím číslom z podacieho denníka, stručné označenie veci, meno referenta, presný obsah návrhu, všetky pozmeňovacie ako aj odročovacie návrhy a rovnako výsledok hlasovania. Pri návrhoch predložených v písomnej forme sa v zápise v zápisnici iba na tento návrh odkázalo. Verejné hlasovanie malo obsahovat informáciu o menách votantov, t.j. hlasujúcich. Zapisovatel'om mal byt’ bud’ najmladší člen zboru, ale spravidla ním bol kancelista.

15 Tieto poznámky obsahujú často údaje o tom ako má byṫ vec po prerokovaní následne vybavená a kto bude za vybavenie zodpovedný. Stretnút sa môžeme aj s informáciami čisto osobného charakteru - rozličné osobné charakteristiky a názory.

16 V niektorých prípadoch ale nájdeme spisové resp. rokovacie čísla napísané farebnou ceruzou na spisových obaloch resp. na zápisniciach zo schôdze.

17 Napríklad v roku 1938, teda v rokoch búrlivých zmien v oblasti autonomistického smerovania Slovenska, pôsobilo celkovo na Filozofickej fakulte UK 23 profesorov, z nich bolo až 17 českej národnosti. Pozri bližšie Dolan, Ondrej - Bartl, Július: Bratislavská univerzita v rokoch 1938-1945. Zborník Filozofickej fakulty Univerzity Komenského v Bratislave HISTORICA, roč. XVII, 1966, s. 6. 
rukopisná verzia. ${ }^{18}$ Zápisnice boli overené vlastnoručnými podpismi prítomných členov zboru. ${ }^{19}$ Každá schôdza profesorského zboru bola z kancelárskeho resp. registratúrneho hladiska spísomnená vo forme spisu (resp. zberného hárku) - obsahoval už spomenutú zápisnicu, niekedy jej rukopisný koncept, pozvánku na schôdzu, ktorá bola vždy napísaná na stroji. Pozvánka obsahovala údaje o dátume, čase a mieste konania schôdze, rovnako obsahovala aj plánovaný program schôdze profesorského zboru, overená bola vlastnoručným podpisom dekana fakulty a niekedy aj odtlačkom úradnej pečiatky. Pozvánka bola doručovaná každému členovi Profesorského zboru Filozofickej fakulty UK. Ďalej býval súčastou spisu o schôdzi profesorského zboru aj zoznam alebo skôr výpis prijatých uznesení a rozhodnutí, ktoré boli priebežne číslované v rámci jednotlivých schôdzí. Dôležitou súčastou týchto spisov bol aj spisový obal. ${ }^{20}$

Filozofická fakulta sa v čase svojho vzniku vnútorne členila na stolice, na čele ktorých stál konkrétny profesor. Okrem samotných stolíc boli vlastnou základnou organizačnou zložkou seminár a proseminár. Na čele seminára stál jeho riaditel'. Niektoré semináre sa d’alej členili na oddelenia. Dekanstvo Filozofickej fakulty sa na začiatku svojej činnosti vnútorne nečlenilo na samostatné organizačné útvary, pretože celkový počet pracovníkov bol pomerne nízky. Na Univerzite Komenského exitovala univerzitná kancelária, ktorá vykonávala vlastne funkciu rektorátu. Na jej čele stále riaditel’ a táto kancelária zabezpečovala činnosti pre rektora, akademický senát, kvestúru, ako aj pre jednotlivé fakulty. Jednotlivým fakultám boli pridelení úradníci tejto kancelárie - rektorátny oficiáli, officianti, ako aj pomocné kancelárske sily. ${ }^{21} \mathrm{~V}$ študijnom roku 1922-1923 jestvovalo na fakulte 9 seminárov: Seminár pre slovanskú filológiu; Seminár historický; Seminár pre obecný národopis; Seminár hudobnej vedy; Seminár pre filozofiu; Seminár pre pedagogiku; Seminár pre germánsku filológiu; Seminár pre romanistiku; Proseminár pre klasickú filológiu. ${ }^{22}$

18 Možná je ale aj varianta, že strojopisný čistopis zápisnice bol v niektorom prípade odstúpený spolu s inými dokumentmi na Ministerstvo školstva a národnej osvety a nazad sa už do registratúry Filozofickej fakulty UK nevrátil.

19 Táto prax pretrvala v podstate až do konca 30. rokov 20. storočia. Odvtedy sa stretávame s funkciou overovatelov zápisníc zo schôdzí profesorského zboru. Bolo to spôsobené nárastom počtu riadnych profesorov fakulty, kedy overovanie zo strany každého člena zboru už spôsobovalo praktické problémy.

20 Ten sa vyskytoval až od schôdze číslo 11. Dovtedy boli jednotlivé dokumenty vedené bez obalu iba vo forme volných listov. Zápisnice boli niekedy zopnuté kancelárskou spinkou.

21 Fakulta od začiatku svojej existencie bojovala nielen v priestorovými problémami, ked’že prakticky až do roku 1936 nemala úplne vyhovujúcu budovu. V tomto roku sa nielen filozofická fakulta, ale aj právnická fakulta a rektorát prestahovali do budovy na Šafárikovom námestí v Bratislave. Problémom boli aj pracovníci fakulty, ktorí mali zabezpečovat administratívu a rutinný chod fakulty. Už pri vzniku fakulty žiadal profesorský zbor Ministerstvo školstva s národnej osvety Československej republiky, aby boli pre fakultu pridelení administratívni a prevádzkoví pracovníci pre dekanstvo. Konkrétne išlo miesta pedela, kancelárskeho oficiála, kancelárskej pomocnej sily, zriadencov - NA, fond Ministerstvo školství I., karton č. 1142, spis č. 5C - 135094 / 1924.; Prehlad personálneho zloženia univerzitnej kancelárie možno nájsţ napríklad v Zoznamoch osôb a ústavov Univerzity Komenského v Bratislave, ktoré boli publikované akademickým senátom univerzity na každý študijný rok. Takýto trend pretrval až do roku 1950 kedy sa už takéto publikácie vydávali výlučne pre jednotlivé fakulty a nie pre celú univerzitu naraz v jednej publikácií. Pozri bližšie: https://uniba.sk/o-univerzite/rektorat-uk/archiv-uk-a/digitalizovane-univerzitne-tlace/

22 NA, fond Ministerstvo školství I., karton č. 1142, sign. 5 III 2, spis č. 135 521/1922, Obsadzovanie funkčných miest vo verejnej správe. 
V nasledujúcich rokoch pribudli aj d’alšie semináre, ako napríklad od roku 1924 seminár pre dejiny umenia, sociologický seminár, seminár zemepisný, seminár pre porovnávací jazykospyt, ako aj anglický seminár. ${ }^{23}$ Napríklad v študijnom roku 1927-1928 okrem vyššie uvedených existovali aj tieto semináre: psychologický, proseminár pre československú literárnu históriu. ${ }^{24}$ Ďalšie nové pracoviská v podobe seminárov a proseminárov vznikli v 30. rokoch. Vznikli ešte seminár estetický, seminár pre pomocné vedy historické, seminár archeologický, proseminár československý jazykový, seminár pre italskú reč a literatúru, proseminár pre mad’arskú filológiu, seminár antropogeografie a aj seminár fyzickej geografie. ${ }^{25}$ Tento systém vnútorného členenia fakulty existoval počas celej existencie prvej Československej republiky.

Z pohladu diplomatickej produkcie seminárov ako aj proseminárov je zaujímavá najmä ich korešpondencia s dekanátom ako aj inými organizáciami. Z dekanátu prichádzali na tieto organizačné zložky fakulty rozličné správy a prípisy. ${ }^{26}$ Vyhotovené boli väčšinou na papieri s predtlačenými údajmi na hlavičke. Písané boli spravidla na stroji. Jazykom bola počas prvej Československej republiky aj v tomto prípade hlavne čeština. Súčastou týchto správ bývali aj odpovede zo strany seminárov adresované dekanátu. Forma bola priamo štylizovaná, bez výrazného individualizmu. Písomnosti zasielané zo seminárov a proseminárov neboli ale vždy písané na stroji. Môžeme sa stretnút aj s rukou písanými dokumentami. Rovnako rukopisný charakter mali aj listy jednotlivých profesorov či d’alších učitelov, ktoré boli zasielané na dekanát. ${ }^{27}$ Jednotlivé záznamy boli protokolované v centrálnom podacom protokole (registratúrnom denníku). Najstarší zachovaný podací protokol Filozofickej fakulty Univerzity Komenského pochádza z roku 1923. V tomto období bol jedným manipulačným rokom študijný rok, ktorý sa označoval a udával v celistvosti. Uvádzal sa v takejto forme aj v spisových a rokovacích číslach.$^{28}$ Podací protokol bol vedený v knihe štandardného formátu A4 na predtlačenom formulári v českom jazyku. ${ }^{29}$ Rovnako po česky sa viedol aj protokol. Podací protokol obsahoval informácie o dátume doručenia alebo odoslania daného podania, rokovacie číslo podania, údaj o odosielatelovi a adresátovi, stručný obsah podania (spisu), dátum odpovede (vybave-

23 Dolan, Ondrej: Univerzita Komenského: prehlad profesorov 1919-1966, prehlad pracovísk 1919-1948. Bratislava 1966, s. 225-239.

24 Novák, J. - Sopušková, A: Filozofická fakulta, s. 12-13.

25 Dolan, O.: Univerzita Komenského, s. 225-239.

26 Išlo vel'mi často o správy o činnosti fakulty, rozličné nariadenia a zadávanie úloh, ktoré mali jednotlivé pracoviská fakulty splnit'. V porovnaní s neskorším obdobím nemali tak direktívny charakter a mali skôr pragmatickú formu.

27 Semináre samozrejme korešpondovali aj navonok, častokrát išlo o korešpondenciu s kolegami z iných vysokých škôl, stretávame sa aj s odbornými a vedeckými textami. Tieto ale mali oficiálny charakter, pretože boli opatrené pečiatkou resp. boli napísané na hlavičkovom papieri fakulty.

28 Prvý zachovaný podací protokol ale má jednu zvláštnost̉ a to, že podacie čísla prechádzajú naprieč kalendárnymi ako aj študijnými rokmi. Záznamy v ňom sú číslované od čísla 1, ktoré bolo pridelené v roku 1923 až po číslo 668, ktoré bolo pridelené až v roku 1925.

29 Protokol tvorí hrubšia úradná kniha, ktorá sa používala od roku 1923 až po rok 1927. Pre rok 1926 už je použitý nový číselný rad. Okrem týchto zapísaných údajov v tomto protokole ale nájdeme aj informácie o výdavkoch z riadnej dotácie pre Historický seminár, ktoré sú zapísané na dovedna šiestich stranách. Tieto zápisy sú vložené uprostred ročníka 1926. 
nia) a stručný obsah vybavenia. Zápisy v podacom protokole boli spravidla velmi stručné, často chýba informácia o vybavení a spôsobe vybavenia. Ďalším zachovaným podacím protokolom v archíve univerzity je ten z roku 1934/1935. Je vyhotovený v knihe obsahujúcej slovenskú predtlač, ale záznamy ma opätovne vedené po česky. Protokol obsahuje údaje o bežnom čísle, dátume doručenia a čísle spisu u odosielatela (ak existuje), obsah veci podania, informáciu o vybavení podania, dátum vypravenia odpovede, údaj o posteriách (nasledujúcom čísle). Záznamy sú taktiež pomerne stručné. V protokole ale navyše nájdeme aj záznamy o skartácií jednotlivých spisov. V porovnaní s prvým protokolom tento obsahuje až 2171 zápisov. $^{30}$

Dôležitou úlohou každej vysokej školy je aj dnes vzdelávanie študentov. Študijné veci mali pomerne bohatú agendu, ktorá sa dotýkala viacerých oblastí - od evidencie študentov a ich študijnej práce až po vydávanie dokladov o nadobudnutom vzdelaní. Filozofická fakulta Univerzity Komenského v Bratislave podobne ako aj iné fakulty univerzity riešila v tomto smere všetky záležitosti ako prvostupňová inštancia. Súčastou začiatku štúdia študentov bolo niekol'ko dokumentov. Tieto sa zakladali do osobných spisov študentov. Ukladané boli abecedne a po ich uzatvorení a odovzdaní do univerzitného archívu sa navyše radili aj podla rokov ukončenia štúdia - absolutória. Prví študenti absolventi ukončili svoje štúdium v roku 1923, odkedy sa zachovali najstaršie spisy skončených študentov. Študenti boli evidovaní v katalógoch. Samostatné katalógy boli vedené pre riadnych ako aj mimoriadnych poslucháčov.

Spis študenta obsahoval doklad o absolutóriu, imatrikulačný list, index, počas samotného štúdia študenta aj jeho maturitné vysvedčenie, domovský list a rodný list. Absolutórium sa vyhotovovalo v latinskom jazyku na predtlačený formulár, ktorý sa vypíňal strojom. Podobne bol vyhotovený aj imatrikulačný list každého študenta. V študijných spisoch ale nájdeme aj rozličné žiadosti študentov, ktoré sa týkali znižovania školného a táx, ktoré boli vyrubované v súvislosti s ich štúdium na univerzite. Rovnako tu možno nájsţ zápisy o vykonaných skúškach a to najmä v prípadoch ak išlo o učitel’ské skúšky, záznamy o klauzúrnych skúškach, rozličné posudky na klasifikačné práce, vysvedčenia o kolokviálnych skúškach a prihlášky na ne. ${ }^{31}$ Medzi písomnostami fakulty samozrejme ale nájdeme aj personálne spisy zamestnancov a to najmä profesorov a d’alších jej učitelov. V porovnaní so súčasnostou je pestrosṫ ako aj množstvo dokumentov v nich uložených výrazne menšia. Obsahujú spravidla pracovnú zmluvu a korešpondenciu týkajúcu sa práce pre fakultu. Nájdeme tu aj rozličné dekréty o plate a odmenách. ${ }^{32}$ Osobné spisy pracovníkov fakulty boli ukladané abecedne.

Zmeny nielen vo fungovaní Filozofickej fakulty ale aj celej univerzity priniesli udalosti rokov 1938. Nielen v súvislosti s vyhlásením autonómie Slovenska v rámci Československej republiky, ale aj následným dočasným zánikom Československej republiky a vznikom samostatného Slovenského štátu v roku 1939 - neskôr Slovenská republika (avšak pod

30 AUK, fond Filozofická fakulta UK, škatul'a č. 1, sg. A - 1. Podacie protokoly.

31 AUK, fond Filozofická fakulta UK, sg. D IV / 1. Skončení 1923/1927 A-Ž.

32 AUK, fond Filozofická fakulta UK, sg. B. Profesori. 
tzv. „ochranou“ Nemeckej ríše) - sa zmenila celková klíma na univerzite. ${ }^{33}$ Univerzita Komenského, ktorá sa už sporadicky od roku 1938 neoficiálne nazývala ako Slovenská univerzita, v roku 1940 zanikla. Na jej mieste bola vytvorená nástupnícka vysoká škola s úradným pomenovaním Slovenská univerzita. ${ }^{34}$ Filozofická fakulta Slovenskej univerzity - čo bolo úradne pomenovanie fakulty z hladiska organizačného, neprekonala zásadnejšie zmeny. Na čele fakulty stál taktiež dekan a zastupoval ho prodekan. Podobne ako v predošlom období mala Filozofická fakulta jedného senátora v akademickom senáte, v tomto prípade už Slovenskej univerzity. Najvyšším kolektívnym orgánom bol profesorský zbor, ktorému predsedal dekan fakulty. Zásadnou zmenou podl’a zákona o zriadení univerzity bola strata autonómie - funkcionárov Slovenskej univerzity vymenúval priamo prezident republiky a neboli volení akademickým senátom ani profesorským zborom. Spočiatku zabezpečovala univerzitná rektorátna kancelária administratívne úlohy aj pre jednotlivé fakulty a teda aj pre Filozofickú fakultu prostredníctvom vyčlenených pracovníkov. Neskôr vznikla kancelária dekanstva Filozofickej fakulty Slovenskej univerzity v Bratislave. ${ }^{35}$ Fakulta sa vnútorne taktiež členila na semináre a prosemináre, ktoré sa d'alej mohli členit na oddelenia. V študijnom roku 1939 - 1940 jestvovali na fakulte tieto semináre a prosemináre: filozofický, sociologický, archeologický, psychologický, estetický, pedagogický, proseminár pomocných vied historických, historický, hudobná veda, dejiny umenia, zemepisný, antropogeografie, fyzickej geografie, slovenského národopisu, porovnávací jazykospyt, slovenská filológia, klasická filológia, románska filológia, italská reč a literatúra, germánska filológia, anglická filológia, mad’arská filológia. V takejto štruktúre pretrvala vnútorná organizačná štruktúra fakulty v podstate až do zániku seminárov v roku $1950 .{ }^{36} \mathrm{Z}$ hladiska písomnej produkcie oproti prechádzajúcemu obdobiu nedošlo k výrazným zmenám. Registratúra fakulty bola aj v tomto období evidovaná v podacích protokoloch a to podla predchádzajúceho modelu - teda jeden registratúrny rok bol jedným študijným rokom. Zmenou bol iba prechod na úradovanie v slovenčine. Zasadnutia profesorského zboru fakulty riešili obdobné záležitosti ako počas prvej Československej republiky. Nezmenila sa ani forma zápisníc z týchto zasadnutí. Okrem ich jazyka ktorý už bol slovenský sa dôsledne zachovával formálna stránka zápisov. Pre obdobie existencie Slovenskej univerzity v Bratislave, ale môžeme v registratúre nájst̉ niektoré nové dokumenty. V oblasti študijnej agendy sa súčastou evidencie stali aj katalógy ktoré obsahovali dotazníky študentov - Nationale. Tieto dotazníky vypĺňali novoprijatí študenti vlastnoručne na predtlačený formulár. Obsahoval meno a priezvisko študenta, miesto narodenia, dátum narodenia, náboženstvo, domovskú obec, štátnu príslušnost',

33 Išlo napríklad o snahy o vypudenie českých profesorov, najmä takých, ktorí presadzovali idei čechoslovakizmu, ktoré nastali už v druhej polovici 30. rokov minulého storočia. Zmeny boli najmä v oblasti nahradenia pôvodne českých profesorov a d’alších učitelov slovenskými odborníkmi. Nielen zápisnice ale aj d’alšie písomnosti univerzity či jej fakúlt sa začali vyhotovovat' výlučne po slovensky. Bližšie pozri: Dolan, O. - Bartl, J.: Bratislavská univerzita, s. 8 - 9.

34 Zákon č. 168/1940 Sl. z. o Slovenskej univerzite v Bratislave; v paragrafe 19 bolo stanovené, že Univerzita Komenského v Bratislave sa zrušuje, pretože sa zrušil aj zákon o jej zriadení.

35 Išlo o osoby: pedel, tajomník fakulty, kancelárske sily a zriadenci dekanátu.

36 Dolan, O.: Univerzita Komenského, s. 225-239. 
národnost', bydlisko, meno a zamestnanie otca, meno a zamestnanie tútora, údaj o poslednom štúdiu, údaje o výnimkách ktoré boli študentovi fakulty prípadne udelené, zápis o imatrikulácií a zložení imatrikulačného sl’ubu, v prípade mužov sa uvádzal aj podrobný záznam o vojenskej povinnosti. Ďalej nasledoval zoznam prednášok - Index, ktorý obsahoval záznamy o zapísaných prednáškach (predmetoch) - jeho presný názov, počet hodín v rámci týždňa, meno docenta (vyučujúceho), vysvedčenie o návšteve. Nakoniec nationale obsahoval aj úradný záznam s pečiatkou dekana fakulty s uvedeným dátumom schválenia a zapísania. Tento dotazník obsahoval ale aj údaje o internátnych poplatkoch (kolejné), poplatky za zápis, či zápis o študijnom príspevku. ${ }^{37}$ Po skončení druhej svetovej vojny bola obnovená Československá republika a fungovanie Slovenskej univerzity sa vrátilo do podobných kolaji ako fungovala Univerzita Komenského počas prvej Československej republiky. Zmeny vo fungovaní po politických zmenách, ktoré priniesol rok 1948, sa prejavili v roku 1950, ked’ bol prijatý vysokoškolský zákon platný v celom Československu. ${ }^{38}$

\section{Diplomatic production of the Faculty of Arts of Comenius University in Bratislava in the years 1921 to 1950}

This study contributes to knowledge of not only Comenius University in Bratislava and its Faculty of Arts, but also has significance for the history of education and science in Slovakia. It deals with the diplomatic production of the Faculty of Arts of Comenius University in Bratislava in the years between 1921 and 1950. This period was not chosen at random, as it was the significant first phase of the operation and gradual development of not only the university, but also of its Faculty of Arts. It records the period in which it was established, as well as the changes that the faculty had to deal with in connection with the development of individual scientific disciplines in the field of social sciences and humanities and how they were gradually established at the Faculty of Arts of Comenius University in Bratislava. The year 1938 was important, as was the year 1940, when Comenius University in Bratislava formally ceased to exist and a new university was established under the name the Slovak University in Bratislava, which assumed all the rights and obligations of Comenius University in Bratislava. It is interesting to observe, however, that this event did not fundamentally affect the administration activities of the university or its Faculty of Arts. Fundamental changes arrived in the year 1950, which marks the end of the period of this study. Throughout the period of this study, the organizational structure of Faculty of Arts was essentially the same. It was headed by the Dean of the faculty and also a vice-dean, and later in the period there were several vice-deans. The collective governing body was the Board of Professors, which decided on all the main issues with regard to the direction and operations of the faculty. Rich file material from the meetings, activities and work of the Board has been preserved. There was also a dean's office, which was responsible for all the administrative operations of the faculty. The faculty offered seminars, which encompassed not only teaching, but also scientific work in individual scientific

37 AUK, fond Filozofická fakulta UK, sg. D - Katalóg riadnych študentov 1938/1939.

38 Zákon č. 58/1950 Zb. z. o vysokých školách. 
Ján Valo

Diplomatická produkcia Filozofickej fakulty Univerzity Komenského v Bratislave v priereze ...

disciplines and specializations. This article is based not only on information from the available literature, but primarily on archive sources that were drawn from the Archives of Comenius University in Bratislava and also from the National Archive in Prague. Documents created at the faculty can be divided into several groups. The files from the meetings of the Board of Professors and the dossiers material on the communication of the faculty with various public bodies and authorities were particularly important. The study documentation also plays an important role as it contains, in particular, the personal files of students and graduates of the faculty. 